\title{
Eastern Donbass Resources as Improvement Factor in the Fuel and Energy Competitiveness Sector of Russia
}

\author{
Mikhail Mikhailovich Afanasiev \\ Olga Anatolievna Tkacheva \\ Irina Anatolievna Getmanova \\ Lyudmila Aleksandrovna Tsurak \\ Olga Andreevna Pavlenko
}

Shakhty Institute of Platov South-Russian State Polytechnic University (NPI)

Email: iskobersi@gmail.com

\section{Doi:10.5901/mjss.2015.v6n3s6p329}

\begin{abstract}
Authors consider possible development ways of the Russia coal industry. Researchers recognize that the world economic crisis had an essential negative impact on the coal industry in general. Research relevance consists in resource analysis of the East Donbass coal basin, whose social and economic situation represents a particular interest in connection with a political situation in the Ukraine border regions, in the Donetsk national republic. East Donbass (160 billion t) is in the west of the Rostov region. Basin coals, as well as in the main Donbass have high quality. The predominant energy, anthracite coal with a high calorific value, there are almost no coking coal. The small power of layers (the majority from several centimeters to $1 \mathrm{~m}$ ), a deep water of development (on average $350 \mathrm{~m}$, the greatest - over $1000 \mathrm{~m}$ ) do an expensive coal rather. The coal industry state and development are defined by the following factors: size of mineral reserves; coal quality; mining-and-geological conditions; mine fund; scientific-technical progress; working conditions; economic factors.
\end{abstract}

Keywords: East Donbass, coal industry, economy, fuel and energy sector, competitiveness.

\section{Introduction}

East Donbass is sufficiently provided with the general geological stocks, which are concentrated in the Donetsk Basin. There are very various qualities of coal: from ineffective brown coals to high-quality anthracites and the valuable coked coals. In Europe, mines with coming nearer to the Donbass conditions for a long time are closed. Recently the last mine in the Ruhr basin in Germany, which on the mining-and-geological conditions is close to Donetsk, stopped work (Kuyumchu, 2003). France, Belgium, and the Netherlands closed the mines already more than 10 years ago, in Great Britain mines removal process also practically comes to the end. Coal in Europe is extracted in Poland, Ukraine (The Donetsk and Lugansk national republics) and Russia, in rather small amounts - in the Czech Republic (Shchadov, 2003). In general, the current state of the coal industry of East Donbass can be characterized as very difficult. Quite a problem researchers estimate the development of the industry (Voskoboynik, 2012; Batyreva, 2002; Isart et all, 2006).

Let's consider the prospect in $20-30$ years. For the past century in Donetsk, basin are extracted 9,4 billion tons of coal, which is more than a quarter of the available stocks. Quite naturally, those layers with rather optimum conditions were fulfilled. Reserves of anthracites in Donetsk, and substantially - in Lugansk area are almost entirely fulfilled; production of the scarce-coked coals decreased. For this reason in the future, there will be a change the extracted coals quality for the worse.

On coal resource, Russia takes the second place in the world, ceding only the USA (Volkov, 2010). Explored reserves in the country make 193,3 billion tons, forecast resources $-3816,7$ billion tons. Some researchers estimate, that at the existing resources production level can be enough for 600 years (Batyreva 2002; Isart et all, 2006).

It is clear that it is an enormous resource, which, nevertheless, not always managed to use rationally. In present conditions, taking into account competitive pressure from other primary energy resources, first of all, natural gas, and also toughening of requirements to environmental standards, the coal industry aims to correspond to the present. Despite 
certain serious problems availability, the coal-mining field of activity continues to develop (Getmanova, 2008).

Russia's coal industry is waiting for the modernization. Researchers believe that within all the XXI century coal will play only temporarily role of "transitional" fuel which it will gradually lose, having passed in the following century leadership to other power sources (Volkov, 2010; Sachsenhofer et all, 2012). Therefore, all the competent Russian authorities at national and sectoral level should be possible to concentrate not so much on the process of extraction and coal trade, but on technology issues its final processing and conversion into finished products, and transformed it trade on the domestic and, in particular, on the external market. It should be noted that researchers of the coal industry of other countries and regions also set this task as the first-priority (Islam, Hayashi,2008).According to the long-term development program by 2030 the industry which settled traditional incentives of growth has to update potential production completely. At the same time, we believe that the availability of the irreconcilable conflict around the Ukrainian part of Donbass causes an inflow of refugees, many of which can be also involved in the Russian coal industry. Despite the seeming ethnocultural proximity of the Russian and Ukrainian people, there are essential distinctions in lingvo-mental and sociocultural base of these people that demands development of additional correctional tools for the Ukrainians arriving at border Russian regions (Karabulatova, Polivara, 2015: 142). In our opinion, propaedeutics of the ethnic-social conflicts (Zamaletdinov et all, 2014; Karabulatova, Al-Jeyran, 2014), undoubtedly, has to be present in the social sphere of the coal industry in a type of severe work conditions (Proskura, 2011).

\section{Materials and Methods}

As materials for research data of the Russian statistics, data of author's inspection of miner's settlements of the Rostov region, polls of local population and experts have served. The received results were compared to the data of experts received earlier as in the field of the coal industry, and other adjacent areas.

The total amount of coal branch financing till 2030 will be 3,7 trillion rubles. Thus, the budget has to allocate only 251,8 billion rubles; that is less than $9 \%$ of total amount for its realization. If to consider that the branch is privatized long ago, the sum does not look scanty. The program assumes that by 2030 , coal mining will grow to 430 million tons and will be carried out on 82 cuts and 64 mines, and labor productivity level (coal mining on one occupied) will exceed an indicator of 2010 (9 thousand tons and 1,88 thousand tons respectively) five times. For the entire period of action of the program 505 million tons of the new and modernized capacities for coal mining - will be entered during the leaving of 375 million tons of capacities of the unpromising and unprofitable enterprises and reduction of the fixed assets wear level from $70-75 \%$ to $20 \%$. Figure 1.

One of the options for classification of the existing perspective directions of use of mineral waste is provided in

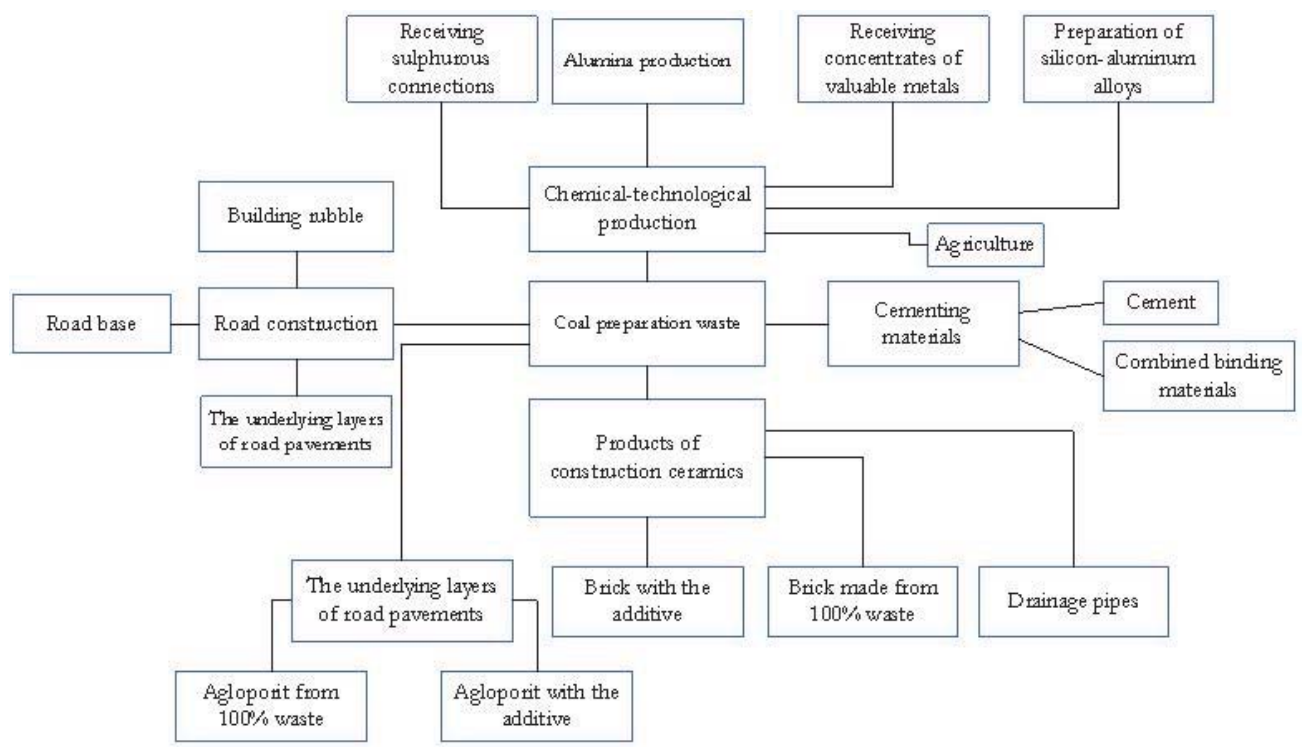

Figure 1. Classification of mineral waste of coal preparation by the directions of their possible use 
On this basis, it is possible to draw a conclusion that possibilities of use of technogenic raw materials of the coal-mining enterprises are rather extensive. Besides, it is also possible to draw a conclusion that creation of a technology complex based on the coal-mining enterprise who would be engaged in additional processing of raw materials reasonably, since it would help to resolve a number of economic, environmental and social issues of the enterprise and the region in which it works. In addition, the raw materials complex use technology possible to use on off-balance reserves of coals.

It is expected that program implementation will lead to a decrease in shipping costs and increase of coal supply efficiency. So, the coal products transportation average range will be reduced by 1,2 times, including in domestic market - by 1,4 times. For decrease in influence of transportation range in the basin local use of the extracted coal for what creation of a number of the power technology complexes allowing passing to coalfields resources development, extraction and methane use is planned will develop. In general, according to the accepted rates of forming of the new coal production centers, there will be a shift of coal mining in the direction of the country east. The share of Eastern Siberia will increase from $25,8 \%$ to $32 \%$, the Far East - from 9,7\% to $15,2 \%$.

In addition, steady innovation system creation for providing the coal industry with perspective, domestic technologies and the equipment, scientific and technical decisions is supposed. At the creation of the new coal centers, mining obligatory construction of modern enrichment factories is provided.

\section{Results}

We are forced to note that there is a decrease in mineral production indicators. So for September 201430127 thousand tons of coal are extracted that on 5073 thousand tons of coal it is less in comparison with the period of last year. This decrease can be explained by the developed negative both political, and economic situation, but also perhaps in it failures in program implementation are connected. Based on the previously mentioned it is possible to draw the following conclusions:

1. The factors providing possibility of increase in production:

- The remaining high potential of production capacities for coal production (as of 01.01.2014-405,9 million tons of coal a year, the utilization rate of capacities following the results of 2013 made 87,3\%);

- Steady demand for the Russian coal in foreign markets.

2. The factors limiting increase in production:

- Decrease in consumption of coal in domestic market, including because of decrease in competitiveness of solid fuel in comparison with natural gas (Topchienko, 2008);

- Decrease in profitability of sales owing to the advancing increase in prices for fuels and lubricants and rates for rail hauling as compared with the level of prices for coal products;

- The high concentration of production in one coal-mining region (Kuznetsk Basin).

These problems solution theoretically has to be solved according to the development program of the Coal industry until 2030. Certain positive moments managed to be reached already now (Kobersy et al., 2015), but it, unfortunately, it is not enough for a full revival of the coal industry. On - to our opinion, it is necessary not only to update OPF, to improve the available processing, but also to create an enterprises complex, depending on operating conditions of the mining organization and the taken raw materials which will maintain the developed power of the coal-mining company.

For application in construction materials production, the greatest interest is represented by the coal preparation waste characterized by the smallest fluctuations of structure and properties. The content of the coal, which is not emitted in the course of enrichment, can reach $10 \%$. Waste of coal preparation is presented usually in the form of pieces by the fineness of 8-80 mm.

Depending on a waste method receipt and their class on fineness, the coal content and respectively the chemical composition and number of plasticity change over a wide range. The greatest number of coal (10-30\%) is in flotation waste. In the waste of gravitational enrichment of a class $1-13 \mathrm{~mm}$ the amount of coal can reach $10 \%$, and in class 13 waste $-150 \mathrm{~mm}$ of $4-7 \%$. In coal, mining waste the coal fluctuates content from 0 to $10 \%$. The Very important limiting factor of application of waste of enrichment of coals is sulfur availability in them. The contents it, for example, in breeds of Donbass reaches $3-4 \%$. Waste humidity depends on their obtaining method. Soapstone natural humidity is $4-5 \%$. The coals flotation waste got from sludge collectors with humidity of $25-30 \%$.

Unlike dump breeds of coal mines waste of coal preparation is characterized by higher content of coal, stable material structure, the smaller content of sandstones and high content of soapstone, increase in the contents is gray also mechanical durability reduction.

Coal waste production and enrichment are used in wall ceramic materials and porous fillers production. On a 
chemical composition, they are close to traditional clay raw materials. As harmful impurity in them there is the sulfur contained in sulfate and sulfide compounds.

At receipt of a brick by a plastic method, the additive of waste makes $0-30 \%$. The introduction of carbonaceous breeds to a certain limit can increase the binding capability of ceramic furnace charge and especially resistance to the squeezing efforts. At rather high maintenance of these breeds in furnace charge (to $20-30 \%$ ) binding capability of clay raw materials sharply decreases. The simplification of conditions of migration of moisture increases drying properties of a raw. Introduction of optimum quantity of a fuel-bearing additive as a result of more uniform roasting improves strength indicators of products (to $30-40 \%$ ), saves fuel, (to $30 \%$ ), and also excludes need of introduction to furnace charge of coal and increases performance of furnaces.

The best additives in ceramic masses are a waste of enrichment of anthracitic coals. If as the main ceramic raw materials soapstone, aerolite's or other breeds products from which after roasting have unsatisfactory structure are used, not frost-resistant and possess unsatisfactory heat-insulating properties. Carbonaceous waste applies as substance, promoting purposeful education in the body of concrete of air or other gaseous time and emaciated additives, which fare entered into the blend in number of $30-40 \%$. For this purpose breeds with the maximum quantity of the burning-out part and high content flying which in the course of roasting do not participate as are removed with combustion gasses before the temperature of their ignition is effective. As productive additives to such ceramic raw materials, also can serve waste of floatation enrichment of gas coals.

Nevertheless, the coal enterprises stand in the same row with the greatest industrial environmental contaminants. Thus, harm of ecology is done not only directly in the course of production, but also it is many years after its termination. One of such adverse effects is climate change towards warming on the planet in general of (Pismennaya et all 2015). These tasks solution demands from the Russian business sector, and the interested government institutions of the coal industry of resuming and continuation of research works on questions of production, transportation and use of water coal fuel (VUT) in power and in the transport sphere.

\section{Discussion}

Over the next three - five years, Russia should simplify the position of the country exporter of coal on the world coal market, as in the last ten - fifteen years there has been a sharp increase in the role of developing countries in global production and consumption of coal (China, India, Indonesia, Venezuela and Colombia) and developed - South Africa and Australia (Lunev, 2007).

For this purpose it will be required: detailed and by country segmentation of the import countries markets of the Russian power and coked coals; transfer of emphasis of gravity of export in the Asian direction (owing to objective energy increase needs in coal the East Asian and South East Asian direction countries); carrying out at the state level of the extremely careful and deeply weighed power policy of restoration of position of Russia as leading export country of coal in the European market, having reasonably and for a long time pushed aside from this direction of the existing and perspective competitors.

Otherwise, Russia can lose the European segment of the world coal market (from the point of view of the power and coked coals export) shortly. Risks in the Russian coal industry development are connected with an entry into the world large manufacturing countries market with large supplies and low costs coal production (China, Indonesia, Malaysia and the Republic of South Africa) (Troitski, 2009). Russia should place the maximum emphasis in strengthening of the export policy on the world coal market, maximizing the foreign trade supply of coal during the next ten - twenty years in connection with the following reasons:

- Deficit of coal in a number of the countries;

- The steady developed foreign trade relations of Russia in the field of export of coal with a number of the states;

- The created leadership in the steam coals import field (Japan, France, Taiwan, the Netherlands, Italy and Denmark, and recently - Germany, Korea, and the USA), and in the coked coals import field (Japan, Korea, Italy, Taiwan, India, Great Britain, Germany, France and Spain).

In the list of the perspective markets, it is necessary to consider Ireland, Belgium, Norway, Sweden, Finland, Iceland, Germany (main foreign trade partner of Russia), Austria, Switzerland, Portugal, Greece; Israel, Turkey; Laos, Malaysia, Thailand, Philippines, Singapore, Taiwan. In far perspective, it is possible to consider Brazil, Argentina, Chile, Paraguay, and Uruguay.

Particular attention should be paid to China. A basis for this purpose is decrease in amounts of production and 
availability of the majority of fields in this country in the future, the enormous growth of need of the country for coal because of spasmodic development of production, geographical proximity and low cost of supply of the Russian and Kazakh coals to the western and northeast regions of China. With China, Russia needs to conduct very moderate foreign trade policy; gradually subordinating to itself the western and northeast segments of the Chinese coal market and forcing out from it completely the USA.

In the circumstances follows Russia is thin to specify the coal export policy on the certain countries. It is necessary to maximize without fail the coal supply to Japan, having perhaps reduced a little selling coal prices and the main thing, having pushed aside Colombia, Canada and perhaps the USA, in the long term and China from this market. On other competitors in the Japanese market, it is hardly possible. The same policy should be pursued concerning Korea, forcing out the USA and Canada. Russia should begin coal supply to the Germany market in which Russia does not participate, forcing out the USA, Canada, and China, and at a competent foreign trade policy in the long term Colombia and perhaps Indonesia. In the market of Great Britain, competitors are the USA, Canada, and China. In the market of Spain - the USA. Russia does not participate in coal supply to India. They should be begun long ago, relying as on the old successful foreign policy and trade relations, on the Indian coal deficit and the geographical proximity of the countries. In the Netherlands market of Russia, it is necessary to lift a share of the participation, having pushed aside the USA, Canada, and China. It also concerns the Italy market. Russia should trying to enter in the short term the Canada coal market though it is very difficult. Russia is owing to the old friendly foreign policy, and external economic relations should increase the share of coal supply to the market of France, exceeding the USA, Canada and in the long term China.

Modern economic development of the countries of the world is characterized by growth tendencies of population size and increase in welfare, scientific and technical progress directions development, electrification of the economy. All this promotes a sharp rise in need of society for different energy types. Moreover, as the primary source of energy is nonrenewable minerals, naturally there is a question of resource base and perspectives of power.

\section{Conclusion}

Therefore, the world economic crisis has the more essentially a negative impact on the coal industry of Russia. In addition to the decrease in coal mining, there is an environmental pollution, depressions strengthening at miners and members of their families. A pollution source is waste heaps. However, just to reclaim waste dumps, after closing of the enterprise, it is appropriate because the piles are rich sources of valuable raw materials and fuels for many processes.

Despite difficulties and risks, prospects of use of raw materials of mountain dumps it is evident since their utilization allows to solve at the same time a number of economic, social and environmental problems, such as:

1. The enterprise has an opportunity to increase the term of the economic life;

2. Jobs preservation;

3. Increase in a range of products;

4. Competitive advantage against similar goods;

5. Improvement and maintenance of a stable ecological situation;

6. Reduction of expenses of the state by land reclamation.

Directly in the extraction and enrichment of coal by-products are used for mines and overburden, waste coal. Mine overburden most frequently represented argillites, siltstones, sandstones, limestone.

Besides, in connection with the decrease in investment appeal of coal mining in a number of the cities and areas the social problems connected with restructuring of mines become aggravated. Most this problem is particularly acute for those settlements where the coal industry is city forming.

In the developed market situation successful competition of products of the coal-mining enterprises in international market and preserving (and even increase) coal export level, and also viability of a number of the coal-mining enterprises of East Donbass, can be provided only on condition of improvement of equipment and technologies for coal mining, cost reduction of production and increase, finally, of technical and economic indicators when providing the high level of labor safety that in turn depends on investment appeal of projects of coal mining.

\section{References}

Batyreva, M.G. (2002) Social and economic effects of restructuring of the coal industry of East Donbass//Mountain information and analytical bulletin (scientific and technical magazine). №2.

Volkov, N.A. (2010) Questions of modernization of the Russian coal industry in the course of its entry into world fuel and energy complex//Problem of the modern economy, №4. 
Voskoboynik, M.P. (2012) The long-term development program of the coal industry of Russia//Mining Industry, No. 2 (96).

Getmanova, I.A. (2008) Economic evaluation of efficiency of use of labour potential in the coal-mining region//Notes of Mining Institute. V. 174. pp. 178-18.

Voskoboynik, M.P. Coal industry problems development of Russia//www.mining-media.ru/ru/article/ekonomic/1164-problemy-razvitiyaugolnoj-promyshlennosti-rossii

Topchienko L.N. (2008) Economic performance of workers enterprise competitiveness. Bulletin of the South-Russian State Technical University (Novocherkassk Polytechnic Institute). Series: Socio-economic sciences No 2. pp 51-54.

Pismennaya, Elena E., Karabulatova Irina S., Ryazantsev Sergey V., Lukyanets Artem S. \& Manshin Roman V. (2015) Impact of Climate Change on Migration from Vietnam to Russia as a Factor of Transformation of Geopolitical Relations. In the: Mediterranean Journal of Social Science. Vol 6, No 3 S2.

Proskura, D.V. (2011) Mechanisms of the solution of the ecology-economic problems caused by effects of restructuring of the coal industry in East Donbass // Terra economics, № 2-3, Volume 9.

Sidorenko, S.A. \& Sidorenko A.A. Coal industry state and perspectives development of Russia. http://www.ibl.ru/konf/031209/14.html.

The coal industry statistics for September 2014 // the Ministry of Energy of the Russian Federation. Coal industry. http://www.minenergo.gov.ru/activity/coalindustry/.

Kobersy I.S., Barmuta K.A., Muradova S.S., Dubrova L.I., Shkurkin D. (2015) The System of the Methodological Principles of Management of Enterprise Development. Mediterranean Journal of Social Sciences. Vol 6, No 3 S4: May 2015 - Special Issue. pp 25-30.

Karabulatova, I.S. \& Polivara Z.V. Intraethnic installation of Ukrainian Labour migrants in the preservation of linguistic and cultural identity. In the: Mediterranean Journal of Social Science. 2015. Vol 6, No3, S2. pp. 142-148.

Kuyumchu, M. (2003) Restructuring of the coal industry and sanitation of mining areas in "new" East lands of Germany//the Mountain information and analytical bulletin (the scientific and technical magazine). №4.

Rogacheva, M.A. \& Antonenko E.E. Processing of technogenic waste as the direction of monotown economy diversification //Electronic magazine "Management of Economic Systems".-http://www.uecs.ru/uecs41-412012/item/1369-2012-05-29-07-37-30 (the date of treatment 18.04.2015).

Komarov, M. A., Alickerov V.A. \& Kusevich V.L. The innovation tekhnoekologiya and new problems of technology mineralogy//Crossindustry scientific and practical magazine "Ecology of industrial production http://ivimi.ru/editions/for_readers/archive/article_ detail.php?SECTION_ID=158\&ELEMENT_ID=12138 (the date of treatment 28.04.2015).

Lunev, A.V. (2007) The coal industry of Russia in world power supply. Abstract of the thesis. Candidate of the economic. Sciences. M. pp. 27.

Troitsky, P.V. (2009) Perspectives of cooperation of Russia and the European Union in the power supply. Abstract of the thesis. Candidate of the economic. Sciences. M. pp. 27.

Schadov, M.I. (2003) Pestrukturization of the coal industry of Poland at the present stage//News of Irkutsk state economic academy. №1, 2003.

Sachsenhofer, R.F., Privalov V.A. \& Panova E.A. (2012) Basin evolution and coal geology of the Donets Basin (Ukrainian, Russia): An overview. In the: International Journal of Coal Geology. Volume 89, Issue 1, pp. 26-40.

Izart A., Sachsenhofer R.F., Privalov V.A., Elie M., Panova E.A., Antsiferov V.A., Alsaab D., Rainer T., Sotirov A., Zdravkov A. \& Zhykalyak M.V. (2006) Stratigraphic distribution of macerals and biomarkers in the Donets Basin: Implications for paleoecology, paleoclimatology, and eustacy. In the: International Journal of Coal Geology Volume 66, Issues 1-2, pp. 69-107.

Islam, M.R. \& Hayashi D. (2008) Geology and coal bed methane resource potential of the Gondwana Barapukuria Coal Basin, Dinajpur, Bangladesh. In the: International journal of coal geology. Volume: 75, Issue: 3. pp. 127-143.

Energy Statistics Yearbook. United Nations. 1997-2007. - New York, 1999-2009; Energy Information Administration, USA, 19942008. 